\title{
Identifikasi Aliran Nilai Tambah Komoditas Unggulan Buah Naga di Kabupaten Banyuwangi
}

\author{
Ayu Sri Lestari dan Eko Budi Santoso \\ Perencanaan Wilayah dan Kota, Fakultas Arsitektur Desain dan Perencanaan, \\ Institut Teknologi Sepuluh Nopember (ITS) \\ e-mail: eko_budi@urplan.its.ac.id
}

\begin{abstract}
Abstrak-Buah naga merah merupakan komoditas unggulan Indonesia dengan produksi terbesar di Banyuwangi. Produksi buah naga di Banyuwangi pada 2014 mencapai 28.819 ton dengan luas lahan 1.152 ha. Kualitas buah naga Banyuwangi telah diakui dalam skala nasional dibuktikan dengan perolehan SERTIFIKAT PRIMA-3 tahun 2010 oleh Kelompok Tani Berkah Naga dan Kelompok Tani Surya Naga tahun 2013. Namun, potensi buah naga tersebut belum dimanfaatkan dengan optimal untuk meningkatkan nilai tambah. Pemasaran dilakukan dalam bentuk buah segar tanpa adanya pengolahan pada pusat pelayanan. Tujuan pemasaran yaitu pasar lokal (5\%), pasar luar kabupaten $(25 \%)$, pasar provinsi $(40 \%)$ dan ekspor ke luar negeri (30\%). Hal ini menunjukkan ketidakefektifan pusat pelayanan berbasis komoditas buah naga sehingga menimbulkan adanya kebocoran wilayah dan hilangnya nilai tambah. Penelitian ini bertujuan untuk mengidentifikasi aliran nilai tambah komoditas unggulan buah naga yang ada di Kabupaten Banyuwangi. Penelitian ini dilakukan dengan metode analisis deksriptif kualitatif dan kuantitatif dengan menghitung jumlah dan rata-rata. Identifikasi dilakukan di 5 (lima) kecamatan sentra penghasil buah naga di Kabupaten dengan jumlah produksi terbesar yaitu Kecamatan Tegaldlimo, Purwoharjo, Bangorejo, Siliragung dan Pesanggaran. Berdasarkan hasil analisis, dapat diketahui bahwa bahwa aliran nilai tambah di tiap kecamatan penghasil buah naga memiliki kesamaan karakteristik, yaitu dari petani ke pengepul dan sebagian besar dijual dalam bentuk buah segar. Pengepul dapat mengumpulkan rata-rata 5-6 ton per hari dari 6-7 petani. Target pasar bagi komoditas buah naga adalah pada 3 lokasi utama yaitu pasar lokal dan PKL, pasar di pusat pelayanan, dan di luar wilayah. Selain itu, penghasilan panen buah naga terbesar oleh petani mencapai 17 ton pada lahan seluas 2 ha. Sedangkan hampir $75 \%$ responden menyatakan bahwa luas lahan yang dimiliki untuk tanaman buah naga yaitu seluas 0,25 ha. Panen buah naga dilakukan 35 hari sekali setelah proses penanaman batang selama 8 bulan.
\end{abstract}

Kata Kunci-Aliran Nilai Tambah, Buah Naga, Pusat Pelayanan, Nilai Tambah.

\section{PENDAHULUAN}

$\mathrm{P}$ ENGEMBANGAN wilayah merupakan upaya membangun dan mengembangkan suatu wilayah berdasarkan pendekatan spasial dengan mempertimbangkan aspek sosial-budaya, ekonomi, lingkungan fisik, dan kelembagaan dalam suatu kerangka perencanaan dan pengelolaan bahwa kegiatan ekonomi tidak didistribusikan pada suatu ruang yang homogen sehingga kegiatan yang bertujuan ekonomi dan sosial merupakan kegiatan yang tersebar sesuai dengan potensi dan nilai relatif lokasi yang mendukungnya. Hal yang sama juga terjadi terkait kesejahteraan penduduk yang erat dengan aksesibilitas terhadap suatu lokasi, dimana kegiatan ekonomi terikat. Salah satu upaya yang dapat dilakukan dalam pengembangan wilayah yaitu dengan pengembangan komoditas unggulan[1].
Berdasarkan data dari PDRB Kabupaten Banyuwangi Tahun 2016, pertumbuhan sektoral PDRB menurut lapangan usaha atas dasar harga berlaku semua sektor mengalami pertumbuhan yang fluktuatif. Sektor pertanian masih merupakan sektor yang memiliki kontribusi tertingggi sebesar 36.39\%. Kemudian, berdasarkan data dari Dinas Pertanian Banyuwangi menyebutkan bahwa ada 7 komoditas unggulan di subsektor tanaman hortikultura berdasarkan besaran produksinya dalam ton yaitu jeruk siam (371.8), buah naga (51.7), manggis (42.9), cabai kecil (25.8), cabai besar (15.18), durian (11.5), dan bawang merah (3.42). Hal ini juga sejalan dengan penelitian yang dilakukan oleh Indra Agung Leksono pada tahun 2016, menyatakan bahwa komoditas unggulan pada sub sektor tanaman hortikultura adalah manggis, buah naga dan jeruk siam. Sejak mulai dikembangkan di Kabupaten Banyuwangi, komoditas unggulan buah naga selalu menunjukkan tingkat pertumbuhan luas panen yang positif.

Buah naga merupakan komoditas yang prospektif untuk dikembangkan karena usaha tani buah naga telah terbukti memberikan keuntungan yang tinggi secara komersial. Permintaan pasar dalam negeri terhadap buah naga dari tahun ke tahun semakin meningkat seiring meningkatnya pendapatan/daya beli masyarakat. Eksistensi buah naga Banyuwangi sebagai salah satu komoditas hortikultura unggulan, kualitasnya telah diakui di skala nasional dibuktikan dengan perolehan SERTIFIKAT PRIMA-3 tahun 2010 oleh Kelompok Tani Berkah Naga dan Kelompok Tani Surya Naga tahun 2013.

Produksi buah naga di Kabupaten Banyuwangi mencapai 28,819 ton dengan luas lahan 1,152 ha pada tahun 2014. Produksi itu meningkat dibandingkan pada 2013 sebanyak 16,631 ton dengan luas lahan 678 ha. Sentra produksi buah naga di Banyuwangi terdapat di Kecamatan Bangorejo, Pesanggaran, Siliragung, Tegaldlimo dan Purwoharjo. Bangorejo menyumbang 39\% dari total produksi buah naga di Banyuwangi atau setara 11,000 ton per ha dengan luas lahan mencapai 449 ha. Buah naga tersebut selain memenuhi pasar lokal Banyuwangi, juga dipasok ke Malang, Surabaya, Bandung, Jakarta dan Bali[2].

Namun, potensi komoditas unggulan buah naga ini belum dapat dioptimalkan. Dalam dokumen RTRW Kabupaten Banyuwangi tahun 2012-2032 menjelaskan bahwa sektor industri belum mampu mengimbangi sektor primer, dalam artian belum dapat mengolah sektor primer menjadi barang setengah jadi maupun barang jadi. Sejak tahun 2012 ditetapkan oleh Pemerintah Kabupaten Banyuwangi sebagai kawasan agropolitan dengan buah naga sebagai salah satu komoditas unggulannya. Jika dilihat dari struktur pelayanan, pusat pelayanan berbasis komoditas unggulan buah naga yaitu ada di Kecamatan Bangorejo, Kecamatan Purwoharjo dan Kecamatan Pesanggaran. Namun, ketiga titik tersebut 
belum berfungsi sebagaimana mestinya. Hal ini terlihat dari besarnya bahan mentah yang keluar tanpa adanya pengolahan terlebih dahulu pada pusat pelayanan dan industri.

Tidak berkembangnya pengolahan (processing) di dalam wilayah diantaranya dipengaruhi oleh kendala pemasaran, lemahnya dukungan kelembagaan petani dan kurangnya dukungan infrastruktur di dalam pusat-pusat kegiatan ekonomi (pusat pelayanan) sehingga menimbulkan dampak berupa kebocoran wilayah[3]. Hasil pertanian buah naga dengan penghasilan 11,000 ton per ha dengan luas lahan mencapai 449 ha langsung dikirim dalam bentuk buah segar ke luar daerah (Surabaya, Bali dan lain sebagainya) maupun ke luar negeri tanpa adanya pengolahan terlebih dahulu[4]. Pernyataan tersebut juga sejalan dengan data dari Dinas Pertanian Jawa Timur yang menyebutkan bahwa komoditas tanaman hortikultura Kabupaten Banyuwangi dipasarkan dalam bentuk buah segar dengan tujuan pasar lokal (5\%), pasar luar kabupaten (25\%), pasar provinsi (40\%) dan ekspor ke luar negeri (30\%).

Berdasarkan pemaparan masalah diatas, maka untuk mengurangi adanya kebocoran wilayah dan meningkatkan nilai tambah dari potensi komoditas buah naga di Kabupaten Banyuwangi, maka dibutuhkan identifikasi aliran nilai tambah komoditas buah naga sebagai langkah awal dalam merumuskan kebijakan, strategi maupun arahan bagi pemerintah dan masyarakat pada umumnya.

\section{METODE PENELITIAN}

\section{A. Jenis dan Pendekatan Penelitian}

Pendekatan yang digunakan dalam penelitian ini adalah pendekatan rasionalistik yang sumber kebenarannya berasal dari empiri dan fakta Jenis penelitian dalam penelitian ini adalah deskriptif kualitatif. Tujuan dari penelitian deskiptif ini adalah untuk membuat deskripsi atau gambaran mengenai situasi atau kejadian, menerangkan hubungan antar fenomena, serta mendapatkan makna dan implikasi dari suatu masalah yang ingin dipecahkan[5].

\section{B. Metode Pengambilan Sampel}

Metode pengambilan sampel yang digunakan dalam penelitian ini adalah probability random sampling yang dilakukan untuk mengambil subjek/sampel secara acak. Dalam proses pengumpulan data dengan wawancara digunakan daftar pertanyaan sebagai acuan terhadap hasil respon yang diharapkan. Transkrip data yang diperoleh dari hasil wawancara yang menjadi input analisis dengan menggunakan metode analisa deskriptif kualitatif dan kuantitatif statistic sederhana.

Responden yang digunakan adalah pihak yang terlibat langsung dalam kegiatan ekonomi buah naga yaitu petani, pengepul dan pelaku usaha industri pengolahan buah naga. Perhitungan sampel petani menerapkan rumus Slovin yang dihitung dari populasi anggota kelompok tani buah naga dengan error $10 \%$ sehingga diperoleh unit sampel sebanyak 100 orang. Berdasarkan data yang diperoleh, populasi petani buah naga di 5 kecamatan sentra penghasil buah naga yaitu 11.166 orang. Berikut rumus Slovin yang digunakan dalam menghitung unit sampel.

$$
n=\frac{N}{1+N e^{2}}
$$

Keterangan:

$\mathrm{n}=$ Unit sampel

$\mathrm{N}=$ Populasi

\section{$\mathrm{e}=$ error}

Selanjutnya, untuk responden pengepul dan pelaku industri pengolahan akan digunakan teknik sampling snowball berdasarkan keterangan dari petani. Pada penelitian ini didapatkan 39 pengepul buah naga dan 6 pelaku usaha pengolahan buah naga di 5 (lima) kecamatan.

\section{Variabel Penelitian}

Variabel-variabel yang dipilih dalam penelitian ini berdasarkan kesesuaian variabel terhadap obyek studi.

Tabel 1.

Variabel Penelitian

\begin{tabular}{ll}
\hline \hline \multicolumn{1}{c}{ Variabel } & \multicolumn{1}{c}{ Definisi Operasional } \\
\hline $\begin{array}{l}\text { Persebaran } \\
\text { komoditas buah }\end{array}$ & $\begin{array}{l}\text { Daerah-daerah yang merupakan penghasil } \\
\text { komoditas unggulan buah naga }\end{array}$ \\
$\begin{array}{l}\text { Jumlah produksi } \\
\text { komoditas buah naga }\end{array}$ & $\begin{array}{l}\text { Statistika hasil produksi komoditas buah naga } \\
\text { per tahun di Kabupaten Banyuwangi }\end{array}$ \\
$\begin{array}{l}\text { Asal bahan baku } \\
\text { (keterkaitan ke }\end{array}$ & $\begin{array}{l}\text { Asal bahan baku industri komoditas buah naga } \\
\text { serta besaran jumlah produksi dari bahan baku }\end{array}$ \\
$\begin{array}{l}\text { Tujuan pemasaran } \\
\text { (keterkaitan ke } \\
\text { depan) }\end{array}$ & $\begin{array}{l}\text { Target pasar dari wilayah hinterland dalam } \\
\text { memasarkan komoditas buah naga dan }\end{array}$ \\
$\begin{array}{l}\text { Aliran komoditas di } \\
\text { pusat pelayanan }\end{array}$ & $\begin{array}{l}\text { Proses aliran produksi komoditas buah naga di } \\
\text { pusat pelayanan }\end{array}$ \\
\hline \hline
\end{tabular}

D. Menganalisis Aliran Nilai Tambah Komoditas Buah Naga di Kabupaten Banyuwangi

Lokasi penelitian dilakukan di 5 (lima) kecamatan penghasil buah naga dengan produksi tebrbesar di Kabupaten Banyuwangi berdasarkan data dari Dinas Pertanian Kabupaten Banyuwangi (Gambar 1). Dalam menganalisis aliran nilai tambah komoditas unggulan buah naga dilakukan dengan analisis deskripsi kualitatif dan kuantitatif.

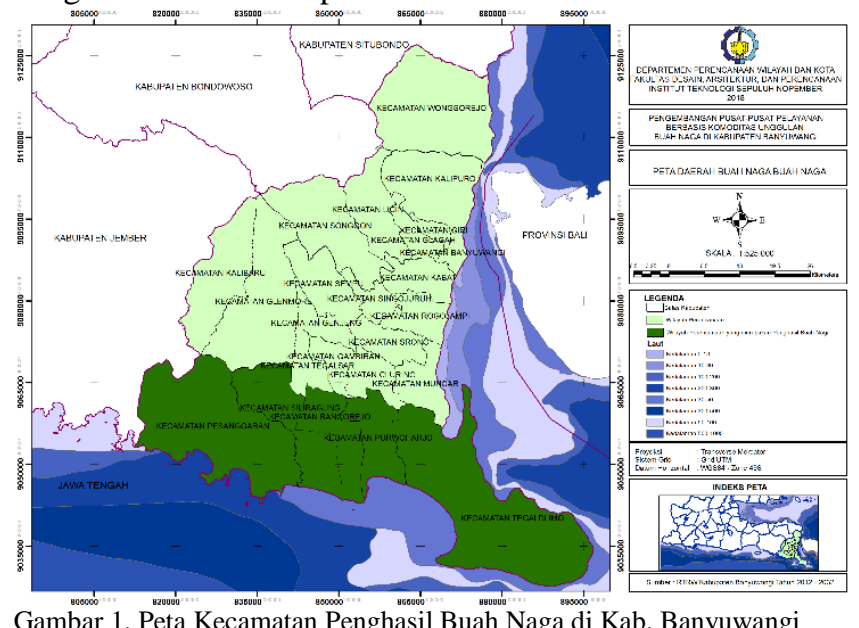

Gambar 1. Peta Kecamatan Penghasil Buah Naga di Kab. Banyuwangi

Ghony (2012) menyatakan bahwa tahapan analisis deskriptif kualitatif meliputi transkrip data hasil wawancara mendalam yang dilakukan, menemukan kata-kata kunci dari hasil wawancara dan mempelajari kata kunci dari verbatim untuk kemudian dianalisis secara deskriptif dari verbatim tersebut[6]. Langkah ini hanya dilakukan untuk menganalisis alasan yang muncul dari verbatim-verbatim responden berkaitan dengan dilakukan atau tidak dilakukannya pengolahan buah naga. Analisis ini juga melibatkan analisis deskriptif kuantatif, dilakukan dengan menghitung nilai mean dari data yang didapatkan bertujuan untuk mendapatkan nilai rata-rata produksi komoditi unggulan yang didapatkan petani, rata-rata produksi komoditi unggulan dari pengepul serta 
alokasi pemasaran. Untuk alur bagan analisis deskriptif aliran nilai tambah dapat dilihat pada Gambar 2.



\section{HASIL DAN PEMBAHASAN}

Berdasarkan hasil analisis aliran nilai tambah ekonomi komoditas buah naga menunjukkan penghasilan panen buah naga terbesar oleh petani mencapai 17 ton pada lahan seluas 2 ha (Tabel 2). Sedangkan hampir 75\% responden menyatakan bahwa luas lahan yang dimiliki untuk tanaman buah naga yaitu seluas 0,25 ha. Panen buah naga dilakukan 35 hari sekali setelah proses penanaman batang selama 8 bulan.

Tabel 2.

Rata-rata hasil panen buah naga

\begin{tabular}{ccc}
\hline \hline No. & Luas lahan (ha) & Hasil panen (ton) \\
\hline 1 & 0,125 & 0,48 \\
2 & 0,25 & 1,31 \\
3 & 0,5 & 5,25 \\
4 & 1 & 9,72 \\
5 & 2 & 17 \\
\hline \hline
\end{tabular}

Pada umumnya, petani langsung menjual hasil panen buah naga ke pengepul. Berdasarkan hasil wawancara dengan para petani buah naga, juga dapat diketahui harga jual buah naga dari petani. Harga yang ada merupakan harga yang berlaku saat survey dilaksanakan.
Perbedaan harga diakibatkan perbedaan waktu survey, sehingga tidak dapat diartikan bahwa harga jual di kecamatan A lebih murah dari kecamatan B.

Tabel 3.

\begin{tabular}{ccc}
\multicolumn{3}{c}{ Rata-rata harga jual buah naga dari petani } \\
\hline \hline No. & Kecamatan & Rata-rata harga jual \\
\hline 1 & Pesanggaran & Rp 2.150 \\
2 & Tegaldlimo & Rp 3.100 \\
3 & Bangorejo & Rp 3.250 \\
4 & Purwoharjo & Rp 3.425 \\
5 & Siliragung & Rp 3.625 \\
\hline \hline
\end{tabular}

Pengepul dapat mengumpulkan rata-rata 5-6 ton per hari dari 6-7 petani. Target pasar bagi komoditas buah naga adalah pada 3 lokasi utama yaitu pasar lokal dan PKL, pasar di pusat pelayanan, dan di luar wilayah.

- Wilayah pertama (pasar lokal dan PKL): pusat pemasaran yang berada di wilayah kecamatan penghasil buah naga yaitu di pasar desa dan atau PKL-PKL yang berjualan di pinggir jalan, biasanya di jalan menuju lokasi wisata atau pusat kota. Buah naga dari pengepul diambil bakul yang kemudian memasarkan buah naga di wilayah ini untuk memenuhi kebutuhan masyarakat yang berlalu lalang (wisatawan).

- Wilayah kedua (pasar di pusat pelayanan): pusat pemasaran yang berada di pusat pelayanan yaitu pasarpasar induk yang terdapat di PPK, PKL, dan PKW dalam lingkup wilayah Kabupaten Banyuwangi. Pemasaran di pasar induk ini untuk melayani kebutuhan masyarakat wilayah pusat kegiatan yang umumnya lebih urban dan populasi penduduknya lebih banyak.

- Wilayah ketiga: dipasarkan ke luar wilayah Kabupaten Banyuwangi, baik dalam lingkup provinsi maupun luar provinsi Jawa Timur. Umumnya, pengepul banyak memasarkan hasil panen buah naga segar (tanpa diolah terlebih dahulu) ke luar wilayah. Tujuan utama pemasaran adalah Kota Surabaya dan Kota Jakarta. Dipasarkan juga ke China, namun proses ekspor dilakukan di Jakarta meskipun buahnya berasal dari Kabupaten Banyuwangi.

Tabel 4

Pemasaran buah naga segar oleh pengepul

\begin{tabular}{|c|c|c|c|c|c|c|c|c|}
\hline \multirow{3}{*}{ Kecamatan } & \multicolumn{8}{|c|}{ Pemasaran } \\
\hline & \multicolumn{2}{|c|}{ Pasar Lokal } & \multicolumn{2}{|c|}{ Pasar di Pusat Pelayanan } & \multicolumn{2}{|c|}{ Lingkup Provinsi } & \multicolumn{2}{|c|}{ Luar Provinsi } \\
\hline & Prosentase & Harga Jual & Prosentase & Harga Jual & Prosentase & Harga Jual & Prosentase & Harga Jual \\
\hline Pesanggaran & $4 \%$ & Rp 2.800 & $5 \%$ & Rp 6.000 & $38 \%$ & Rp 8.300 & $63 \%$ & Rp 13.400 \\
\hline Tegaldino & $8 \%$ & Rp 3.800 & $12 \%$ & Rp 6.100 & $41 \%$ & Rp 8.750 & $67 \%$ & Rp 14.200 \\
\hline Bangorejo & $8 \%$ & Rp 4.000 & $22 \%$ & Rp 6.800 & $44 \%$ & Rp 9.500 & $81 \%$ & Rp 14.700 \\
\hline Purwoharjo & $10 \%$ & Rp 4.000 & $10 \%$ & Rp 7.000 & $37 \%$ & Rp 10.200 & $74 \%$ & Rp 15.500 \\
\hline Siliragung & $5 \%$ & Rp 4.500 & $10 \%$ & Rp 7.750 & $46 \%$ & Rp 10.500 & $64 \%$ & Rp 16.400 \\
\hline
\end{tabular}

Berdasarkan Tabel 4, dapat diketahui bahwa rata-rata prosentase pemasaran buah naga segar paling banyak dilakukan di luar wilayah Kabupaten Banyuwangi. Sedangkan untuk pelaku industri, terdapat beberapa industri olahan skala rumah tangga yaitu pengolahan dodol, minuman, mie, dan nasi goreng buah naga. Namun, kecenderungan yang terjadi di hampir seluruh wilayah penelitian bahwa sebagian besar komoditas buah naga yang dipasarkan tidak mengalami pengolahan. Komoditas buah naga dijual dalam bentuk buah segar saja sehingga dapat disimpulkan bahwa kurangnya pertambahan nilai melalui proses pengolahan bagi komoditas unggulan ini.

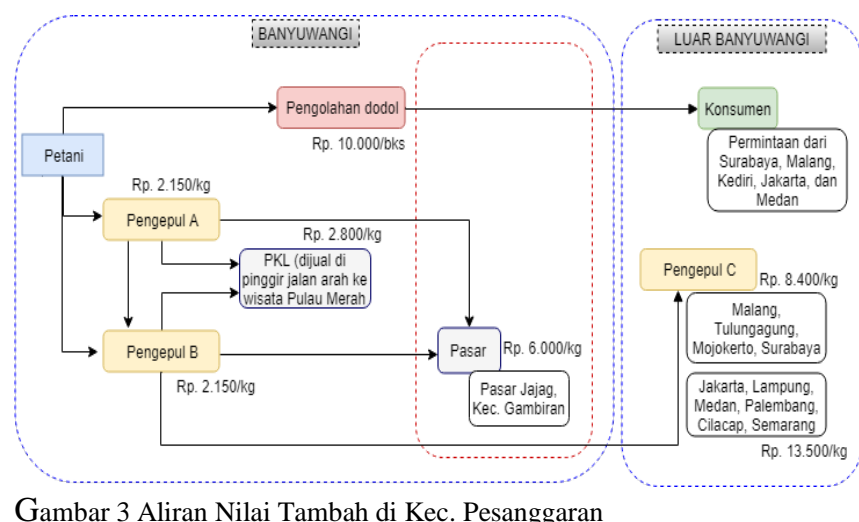

Gambar 3 Aliran Nilai Tambah di Kec. Pesanggaran

Berdasarkan Gambar 3 dapat diketahui bahwa buah naga dari petani sebagaian besar langsung diserahkan ke pengepul, baik pengepul A dan B. Perbedaaan dari pengepul A dan B 
hanyalah pada kemampuan pengiriman ke luar Kabupaten Banyuwangi. Harga jual ke pengepul A sama dengan harga jual ke pengepul B. Hanya saja, apabila pengepul A ingin melakukan pengiriman keluar Kabupaten Banyuwangi, maka dia akan menitipkan buah naga ke pengepul B dengan membayar Rp 500-1.000/kg.

Kemudian, dari pengepul dijual ke PKL di pinggir jalan arah ke wisata Pulau Merah dan Teluk Hijau. Pemasaran juga dilakukan ke pasar-pasar di pusat pelayanan seperti ke Pasar Jajag yang ada di Kecamatan Gambiran serta pemasaran ke luar wilayah Kabupaten Banyuwangi. Harga buah naga segar yang tertera pada pengepul C (pengepul luar kota) bukanlah merupakan harga yang beredar di pasaran. Selain itu, di Kecamatan Pesanggaran juga terdapat industri rumah tangga pengolahan buah naga menjadi dodol. Berdasarkan hasil wawancara, menunjukkan bahwa pengolahan dodol diolah dari $4 \mathrm{~kg}$ buah naga menjadi $2 \mathrm{~kg}$ dodol yang kemudian dikemas menjadi 10 bungkus mika. Per bungkus mika dihargai Rp 10.000 yang dipasarkan secara online melalui Facebook atau grup WhatsApp dan dikirim melalui jasa kurir. Pengolahan dilakukan sesuai pesanan dan dilakukan di rumah pribadi. Permintaan akan produk olahan seluruhnya dari luar wilayah Kabupaten Banyuwangi.

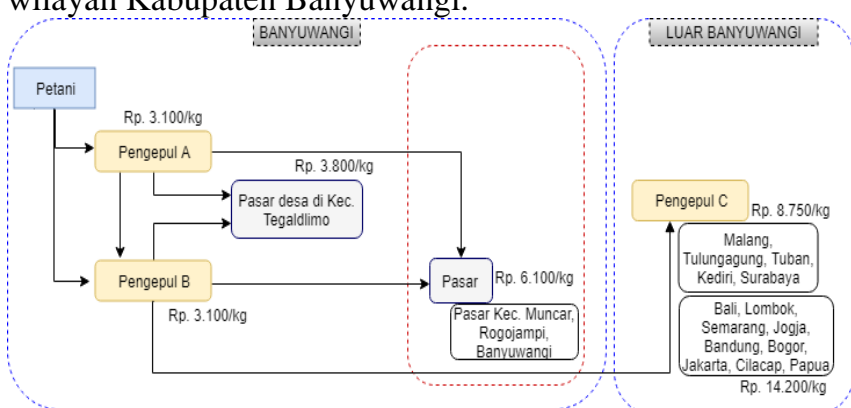

Gambar 4 Aliran Nilai Tambah di Kec. Tegaldlimo

Berdasarkan Gambar 4 dapat diketahui bahwa buah naga dari petani sebagaian besar langsung diserahkan ke pengepul, baik pengepul A dan B. Kemudian, dari pengepul dijual ke pasar lokal yang ada di Kecamatan Tegaldlimo sendiri dan pasar-pasar di pusat pelayanan seperti di Kecamatan Muncar, Rogojampi dan Banyuwangi. Selain itu, buah naga segar juga dijual ke luar wilayah Kabupaten Banyuwangi seperti Bali, Semarang dan Jakarta. Harga buah naga segar yang tertera pada pengepul C (pengepul luar kota) bukanlah merupakan harga yang beredar di pasaran. Kecenderungan di Kecamatan Tegaldlimo ini yaitu petani langsung menjual hasil panen ke penegepul dan belum berkembang adanya industri ataupun pelaku usaha pengolahan buah naga.

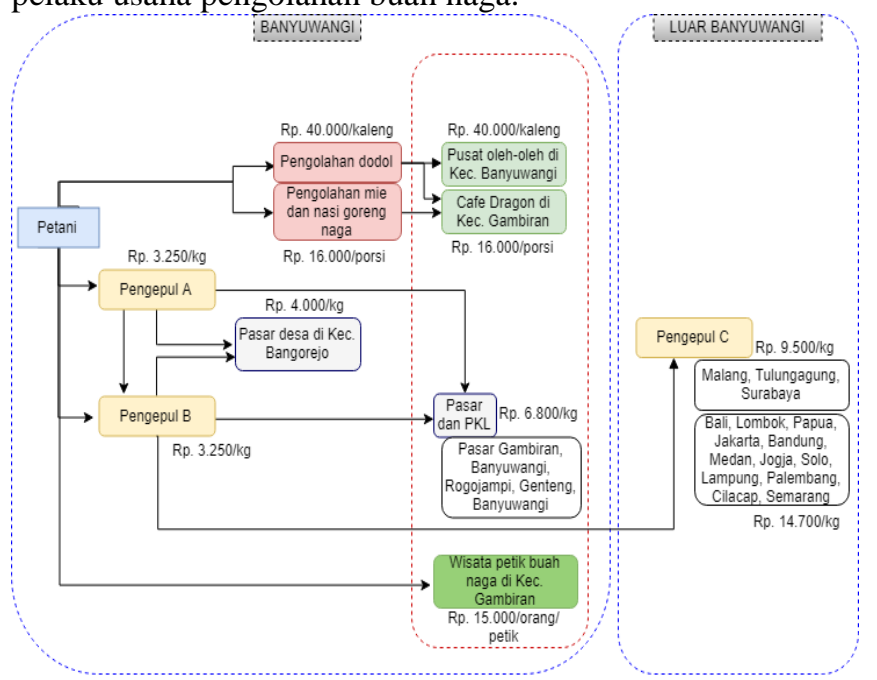

Gambar 5 Aliran Nilai Tambah di Kec. Bangorejo
Berdasarkan Gambar 5 dapat diketahui bahwa buah naga dari petani sebagaian besar langsung diserahkan ke pengepul, baik pengepul A dan B. Kemudian, dari pengepul dijual ke pasar lokal yang ada di Kecamatan Bangorejo sendiri dan pasar-pasar di pusat pelayanan seperti di Kecamatan Gambiran, Genteng, Rogojampi dan Banyuwangi. Selain itu, buah naga segar juga dijual ke luar wilayah Kabupaten Banyuwangi seperti Malang, Surabaya, Semarang dan Jakarta. Harga buah naga segar yang tertera pada pengepul C (pengepul luar kota) bukanlah merupakan harga yang beredar di pasaran.

Selain itu, di Kecamatan Bangorejo juga terdapat industri rumah tangga pengolahan buah naga menjadi dodol dan olahan mie dan nasi goreng buah naga. Berdasarkan hasil wawancara, menunjukkan bahwa pengolahan dodol diolah dari $20 \mathrm{~kg}$ buah naga menjadi $10 \mathrm{~kg}$ dodol yang kemudian dikemas menjadi 20 kaleng @ Rp 40.000; sedangkan mie buah naga dari 1 kg buah naga menjadi 10 porsi @ Rp 16.000; dan nasi goreng naga dari $1 \mathrm{~kg}$ buah naga menjadi 7-8 porsi @ Rp 17.000. Pemasaran dilakukan di pusat oleh-oleh di Kec. Banyuwangi dan Café Dragon di Kec. Gambiran. Pengolahan dilakukan di rumah pribadi (dodol) dan di café (mie dan nasi goreng buah naga). Wisata petik buah naga ada di sekitar Café Dragon dengan biaya petik Rp.15.000/orang/kg

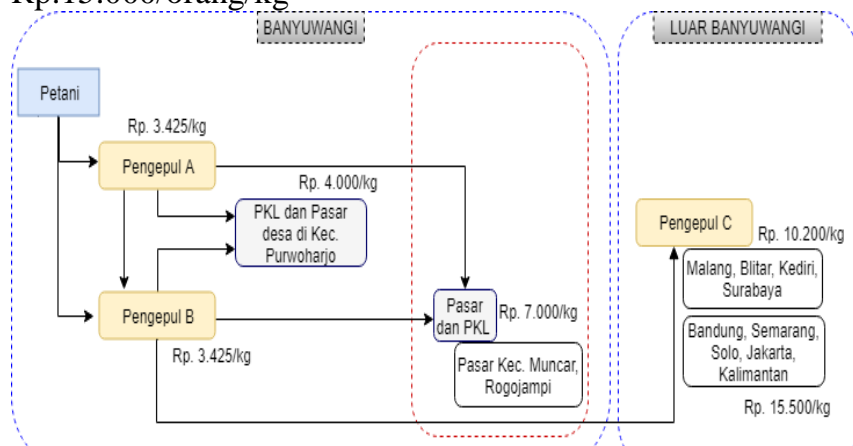

Gambar 6 Aliran Nilai Tambah di Kec. Purwoharjo

Berdasarkan Gambar 6 dapat diketahui bahwa buah naga dari petani sebagaian besar langsung diserahkan ke pengepul, baik pengepul A dan B. Kemudian, dari pengepul dijual ke pasar lokal yang ada di Kecamatan Purwoharjo sendiri dan pasar-pasar di pusat pelayanan seperti di Kecamatan Muncar dan Rogojampi. Selain itu, buah naga segar juga dijual ke luar wilayah Kabupaten Banyuwangi seperti Surabaya, Jakarta, Kalimantan. Harga buah naga segar yang tertera pada pengepul C (pengepul luar kota) bukanlah merupakan harga yang beredar di pasaran. Kecenderungan di Kecamatan Tegaldlimo ini yaitu petani langsung menjual hasil panen ke pengepul dan belum berkembang adanya industri ataupun pelaku usaha pengolahan buah naga.

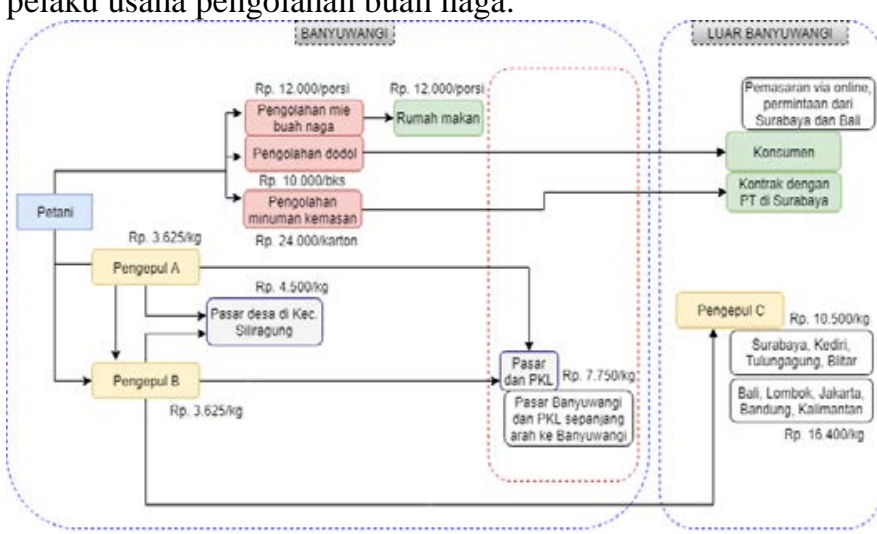

Gambar 7 Aliran Nilai Tambah di Kec. Siliragung 
Berdasarkan Gambar 7 dapat diketahui bahwa buah naga dari petani sebagaian besar langsung diserahkan ke pengepul, baik pengepul A dan B. Kemudian, dari pengepul dijual ke pasar lokal yang ada di Kecamatan Siliragung sendiri, PKLPKL di pinggir jalan arah ke pusat kota dan pasar-pasar di pusat pelayanan seperti di Kecamatan Banyuwangi. Selain itu, buah naga segar juga dijual ke luar wilayah Kabupaten Banyuwangi seperti Surabaya, Jakarta, dan Bandung. Harga buah naga segar yang tertera pada pengepul C (pengepul luar kota) bukanlah merupakan harga yang beredar di pasaran.

Selain itu, di Kecamatan Siliragung juga terdapat industri rumah tangga pengolahan buah naga menjadi dodol, mie buah naga, dan minuman kemasan. Berdasarkan hasil wawancara, menunjukkan bahwa pengolahan dodol diolah dari $5 \mathrm{~kg}$ buah naga menjadi $3 \mathrm{~kg}$ dodol yang kemudian dikemas menjadi 15 bugkus mika, harga per mikanya Rp 10.000. Dodol dijual via online melalui Facebook dan grup WhatsApp kemudian dikirimkan melalui jasa kurir. Mie buah naga diolah dari $1 \mathrm{~kg}$ buah naga menjadi 8-10 prosi mie yang dijual dengan harga Rp 12.000. Mie buah naga dijual di sebuah kedai rumah makan di Kecamatan Siliragung. Sedangkan produk olahan minuman kemasan diolah dari 11 kg buah naga menjadi 30 karton yang bersisi 32 gelas minuman, per kartonnya dijual dengan harga Rp 24.000. Saat ini, pengolahan minuman kemasan telah kontrak dengan salah satu PT di Surabaya, sehingga pemasaran tidak dilakukan di tempat lain.

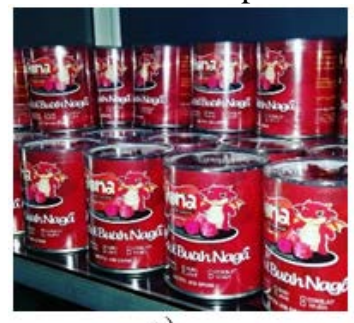

a)

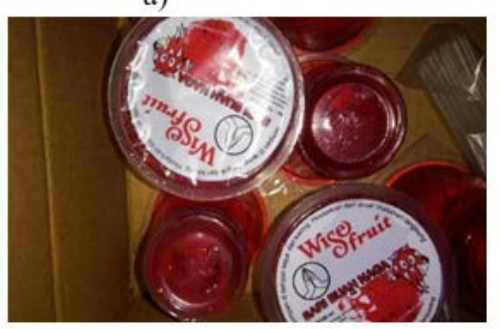

c)

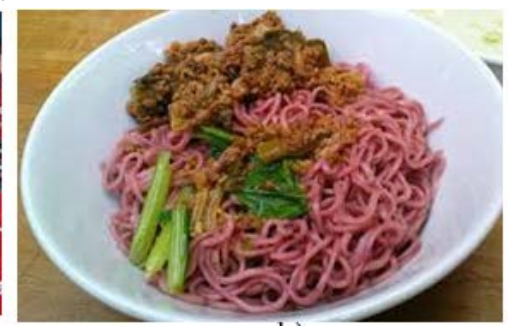

b)

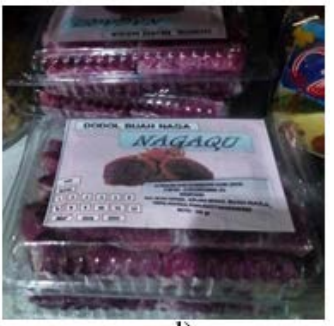

d)
Gambar 7. Aliran Nilai Tambah di Kec. Siliragung, a) dodol kaleng; b) mie buah naga; c) minuman buah naga; d) dodol mika

Dari penggambaran aliran nilai tambah komoditas unggulan buah naga di wilayah Kabupaten Banyuwangi dapat disimpulkan beberapa poin berikut, antara lain adalah intrepretasi forward dan backwawrd linkage, nilai tambah komoditas, dan alasan dilakukan/tidaknya pengolahan. Dalam memandang kaitan ke belakang serta kaitan ke depan yang terjadi pada komoditas buah naga, peneliti dalam hal ini menggunkaan sudut pandang dari titik sektor kegiatan perdagangan buah naga yang dilakukan oleh pengepul.

\section{Intrepretasi Backward Linkages}

Sektor kegiatan sebagian besar yang ada yaitu perdagangan buah naga dalam bentuk buah segar saja yang berlangsung antara petani-pengepul-konsumen, meski ada sebagian kecil aliran nilai tambah yang terjadi yaitu dari petani - pengepul - pengolahan - konsumen. Hal ini menunjukkan bahwa antara keterkaitan ke belakang yang terjadi yaitu keterkaitan antara pengepul dan petani saja. Artinya, kegiatan perdagangan yang dilakukan oleh pengepul mendapat sumbangan input dari petani yang berupa buah segar saja.

\section{Intrepretasi Forward Linkages}

Kaitan ke depan menggambarkan keterkaitan antara kegiatan yang menghasilkan output untuk digunakan sebagai input bagi kegiatan berikutnya. Aliran nilai tambah komoditas buah naga pada penelitian ini berlangsung dari petani - pengepul - konsumen dan petani - pengepul pengolahan - konsumen. Pengolahan hanya terjadi pada sebagian kecil dari total produksi buah naga di Kabupaten Banyuwangi. Output yang dihasilkan berupa olahan makanan dan minuman.

\section{Nilai Tambah Komoditas}

Proses pengolahan ini memungkinkan adanya pertambahan nilai ekonomi bagi komoditas dari segi harga jual. Nilai tambah yang disebabkan adanya pengolahan terjadi di tingkat petani yang memanfaatkan buah naga dengan kualitas rendah (BS/Bekas Sortir) agar tidak terbuang sia-sia. Produk turunan buah naga yang ada di wilayah Kabupetan Banyuwangi meliputi dodol, mie buah naga, nasi goreng buah naga dan minuman kemasan. Selain itu, nilai tambah yang terjadi yaitu pada sektor pariwisata dengan memanfaatkan kebun buah naga sebagai wisata petik buah naga.

\section{Alasan Dilakukan/Tidaknya Pengolahan}

Berdasarkan hasil analisa deskriptif yaitu dengan menelaah pendapat responden mengenai alasan yang menyebabkan dilakukan/tidaknya pengolahan. Dari sekian banyaknya faktor penyebab dilakukan/tidaknya pengolahan oleh responden, faktor yang keluar sebagai output adalah yang berulang minimal terkonfirmasi oleh 3 (tiga) responden. Diketahui juga ternyata ada faktor internal, dimana kegiatan pengolahan tidak dilakukan karena dipengaruhi kondisi nyata responden. Semantara lingkup pembahasan peneleitian adalah mencari faktor eksternal yang tidak datang dari pribadi responden tetapi kemampuan pusat pelayanan. Adapun penyebab dilakukannya pengolahan lebih banyak dipengaruhi oleh faktor internal yaitu keinginan berwirausaha dan memanfaatkan buah naga yang kualitasnya rendah dan tidak laku di pasaran, dan faktor eksternal yaitu adanya dukungan dari Disperindag melalui program pelatihan pengolahan buah naga. Sedangkan penyebab tidak dilakukannya pengolahan antara lain:

ketiadaan prasarana-sarana pengolahan

tidak ada industri pendahulu

ketiadaan pusat pemasaran

Berdasarkan alasan-alasan yang menyebabkan dilakukan/ tidaknya pengolahan terhadap komoditas unggulan buah naga, terlihat bahwa perlunya peran yang signifikan dari suatu pusat pelayanan bagi pengembangan komoditas unggulan buah naga. Sedangkan alasan dilakukannya pengolahan adalah untuk memanfaatkan buah naga dengan kualitas rendah agar tetap memiliki nilai jual.

\section{KESIMPULAN}

Pada penelitian ini bertujuan untuk mengidentifikasi aliran nilai tambah komoditas unggulan buah naga yang ada di Kabupaten Banyuwangi, khususnya di 5 kecamatan sentra penghasil buah naga di Kabupaten dengan jumlah produksi terbesar yaitu Kecamatan Tegaldlimo, Purwoharjo, Bangorejo, Siliragung dan Pesanggaran. Berikut ini hasil yang diperoleh dari penelitian ini antara lain: 
Dari hasil analisis yang dilakukan untuk melihat aliran nilai tambah dari komoditas unggulan buah naga, dapat diketahui bahwa kegiatan perekonomian buah naga berlangsung pendek, yaitu sebagian besar penjualan buah segar saja, meskipun ada beberapa industri pengolahan yang berkembang.

Pengolahan buah naga yang ada di Kabupaten Banyuwangi yaitu minuman kemasan, mie buah naga, nasi goreng buah naga, dan dodol buah naga. Selain itu, juga terdapat keterkaitan dengan sektor pariwisata untuk meningkatkan nilai tambah.

Penyebab tidak dilakukannya pengolahan antara lain: ketiadaan prasarana-sarana pengolahan, tidak ada industri pendahulu, dan ketiadaan pusat pemasaran.

Berdasarkan hasil penelitian, maka saran/rekomendasi pengembangan wilayah Kabupaten Banyuwangi berdasarkan potensi komoditas buah naga yaitu dengan pembangunan STA (Sub Terminal Agribisnis), penguatan kemitraan dan pemberdayaan masyarakat dalam mengolah potensi lokal, khusunya buah naga.

\section{DAFTAR PUSTAKA}

[1] A. Alkadri, D. S. Riyadi, M. Siswanto, and M. Fathoni, Manajemen teknologi untuk pengembangan wilayah : konsep dasar, contoh kasus, dan implikasi kebijakan. Jakarta: Pusat Pengkajian Kebijakan Teknologi Pengembangan Wilayah, Badan Pengkajian dan Penerapan Teknologi, 1999

[2] A. L. Jayanti and M. Muksin, "Analisis stakeholder dalam agribisnis nuah naga di Kecamatan Bangorejo Kabupaten Banyuwangi,” J. Ilm. Inov., vol. 15, no. 3, pp. 99-107, 2015.

[3] A. Jaya, "Kebocoran wilayah dalam sistem agribisnis komoditas kayu manis rakyat serta dampaknya terhadap perekonomian wilayah (kasus Kabupaten Kerinci Provinsi Jambi),” Institut Pertanian Bogor, 2009.

[4] K. P. Prapti, R. Iskandar, and K. Kasutjianingati, "Strategi peningkatan konerja supplay chain buah naga di Kecamatan Bangorejo Kabupaten Banyuwangi berdasarkan proses inti scor," $J$. Ilm. Inov., vol. 15, no. 3, pp. 94-98, 2015.

[5] N. Muhadjir, Metodologi penelitian kualitatif: telaah positivistik rasionalistik, phenomenologik realisme metaphisik. Yogyakarta: Rake Serasin, 1990.

[6] D. Ghony, M and F. Almanshur, Metodologi Penelitian kualitatif. Jakarta: Ar-ruzz Media, 2012. 